\title{
Range Burning
}

\section{HENRY A. WRIGHT}

Highlight: There are many uses for prescribed burning in the management of forests, chaparral, grasslands, watersheds, and wildlife. Some of these uses have been pointed out in this paper. There are also many dangers in using fire, both in its application and in its results. To minimize harmful effects, fire should never be used during extended dry periods; burns should always take place when the soil is damp or wet. Moreover, the user should be an experienced professional with a thorough knowledge of ecosystems, weather, and fire behavior.

We know a lot about the effect of fire on western rangelands and its value as a tool, but information necessary to conduct specific prescribed burns is generally inadequate or nonexistent. Thus, the use of fire is frightening, and many desirable prescribed burns just don't get started. Few land managers have the training or courage to conduct a burn. Most have been exposed only to catastrophic fires, which are untimely, have undesirable effects, and scare everyone in their path.

There are other fears which inhibit prescribed burning. One is a fear of the liability consequences if a fire gets away. This fear affects individual landowners and also influences government agencies. Another fear, which has been important in the past but may be less so now, is a concern about one's career if he lets a fire get away.

In this paper I intend to point out the usefulness of prescribed burns in many plant communities, the reasons why most wildfires are detrimental, and how prescribed burns can be conducted. Hopefully, it will stimulate some thinking and encourage others to use fire as it has been used in parts of the West.

The author is professor of range management, Department of Range and Wildlife Man agement, Texas Tech University, Lubbock.

The paper is a contribution of the College of Agricultural Sciences, Texas Tech University, No. T-9-128.

Manuscript received August 2, 1973

\section{Use of Fire as a Tool}

Where prescribed burning is an applicable tool, many objectives can be achieved simultaneously. Increased herbage yields, increased utilization, increased availability of forage, improved wildlife habitat (more food with unburned patches for cover), control of undesirable shrubs, a mineral seedbed for establishment of commercial trees, and control of various diseases (e.g. liver fluke and brownspot) can all be achieved with one burn. For example, in mesquite (Prosopis glandulosa)-tobosa (Hilaria mutica) communities in west Texas (Fig. 1), we usc fire to (a) remove accumulated litter, (b) increase yields of tobosa (Fig. 2), (c) increase palatability of tobosa, (d) reduce mesquite canopy to acceptable levels, (e) top-kill mesquite and leave the stems in a state where wood borers will attack and aerate them to such an extent that they will be easily consumed by a reburn, (f) kill 40 to $80 \%$ of three species of cactus, and (g) kill undesirable annual broomweeds (Xanthocephalum dracunculoides) (Wright, 1972a). By contrast, spraying this same community with $2,4,5-\mathrm{T}$ will not increase yields of tobosa (Dahl et al., 1971), will not increase palatability of tobosa, will not kill pricklypear (Opuntia phaeacantha) or cholla (O. imbricata), and will leave the wood of mesquite resistant to wood borers.

Fire also achieves multiple objectives in the aspen parkland of Alberta, Canada.
Fall or spring burns in the aspen forest (a) top-kill all woody plants such as quaking aspen (Populus tremuloides), snowberry (Symphoricarpos occidentalis), rose (Rosa woodsii), raspberry (Rubus strigosus), gooseberry (Ribes oxyacanthoides), willow (Salix sp.), and silverberry (Elaeagnus commutata), (b) provide a seedbed for the establishment of forage seedlings, (c) increase the supply of palatable browse for cattle, (d) sharply increase the food supply and habitat for white-tail deer and ruffed grouse, and in the grasslands (a) eliminate litter buildup from rough fescue on north-facing slopes, and (b) during wet years maintain stable forage yields (Bailey, 1972, personal communication).

Management after a burn is essential for obtaining desirable results. Grazing animals will frequently concentrate on a burn because the feed is more palatable, nutritious, and readily available. For this reason burning must be done on a manageable unit basis. If small areas within large pastures are burned, animals will concentrate on the burn, regardless of how long the rancher waits to turn the animals in. This is why burns are often criticized for killing the grass when in reality they probably produce more grass than control areas. Moreover, burning small areas may be an effective way to get animals to overbrowse some species such as aspen and thus destroy some brush.

\section{Prescribed Burns vs Wildfires}

Because of the variety of seasons and weather conditions in which a burn can occur, one must be careful how he interprets the results of a fire study. If the data is from a wildfire, the fire probably occurred during a very dry year. If the data is from a prescribed burn, the fire probably occurred during a wet year. 


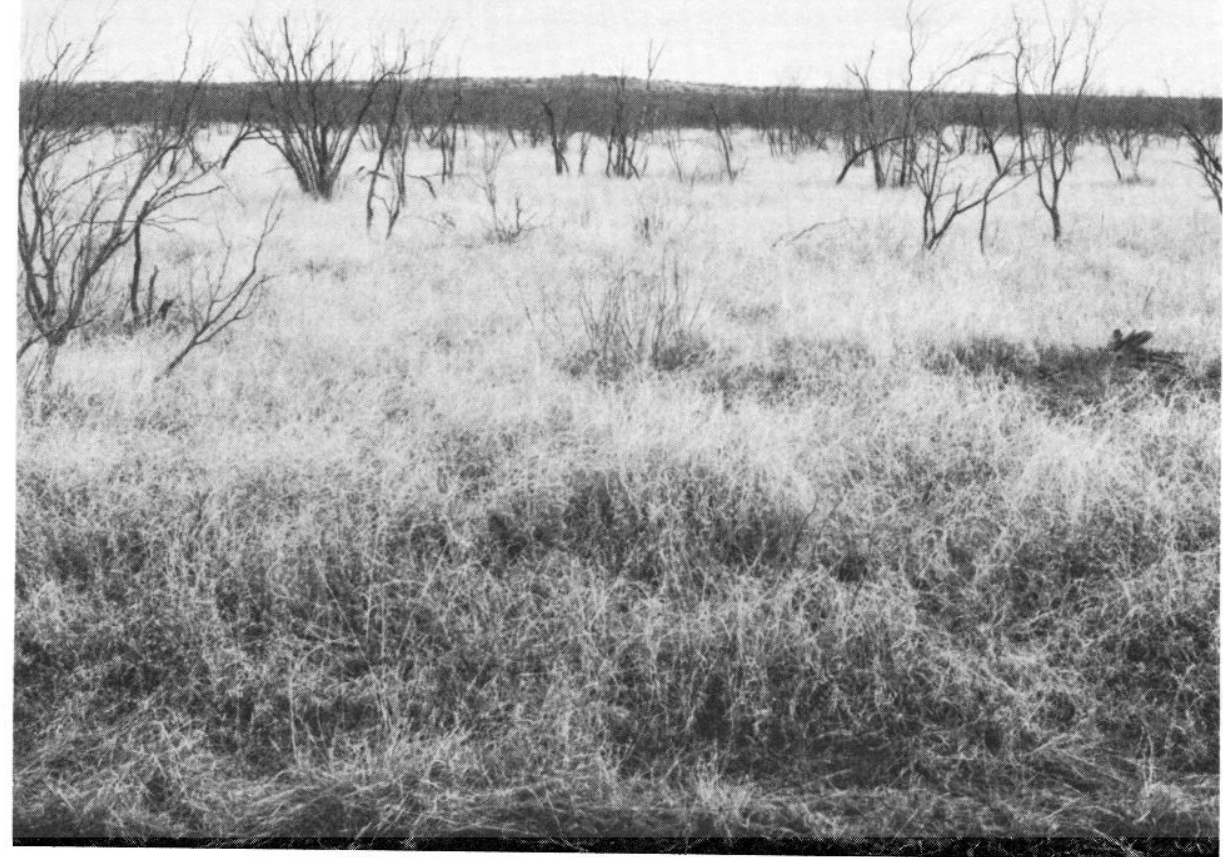

Fig. 1. A sprayed mesquite-tobosa community in west Texas. Dead plant material is in excess of 5,000 lb/acre, and annual grass yields are only 1,100 lb/acre. The dead standing mesquite stems are also an obstacle in handling livestock.

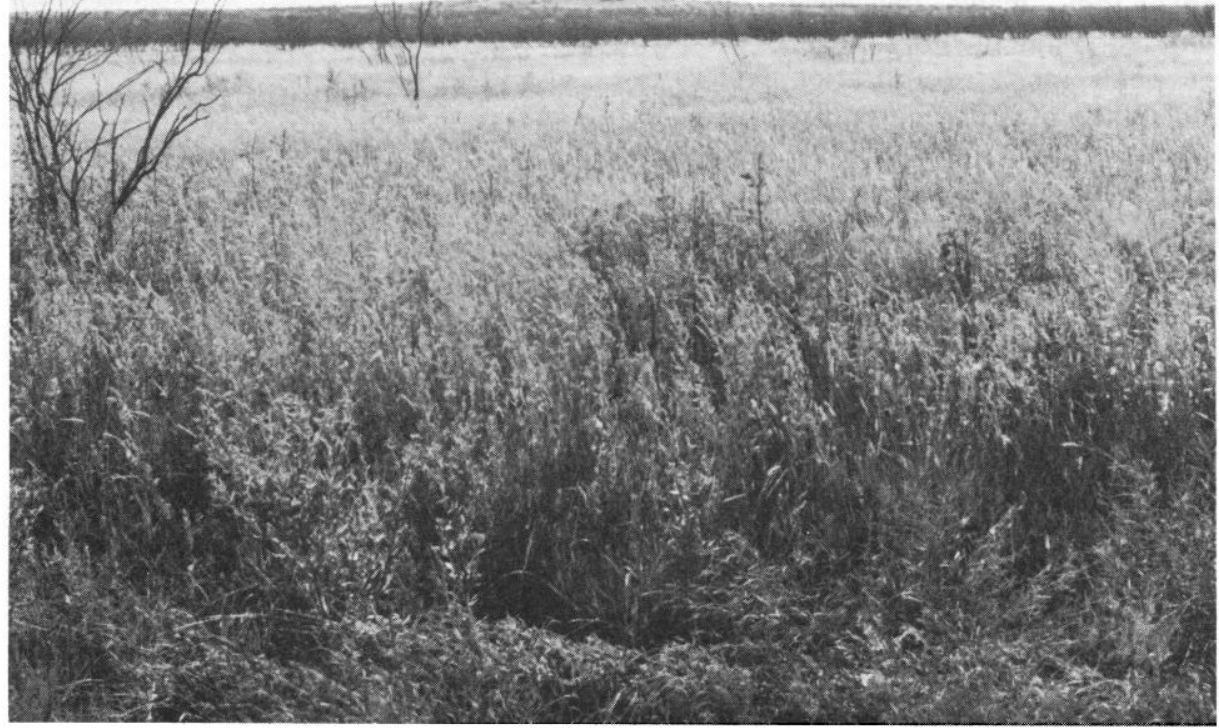

Fig. 2. A mesquite-tobosa community 3 months after burning. Current grass production is about 3,000 lb/acre, and most mesquite stems have been burned down. Resprouts of the trees have been suppressed and 30\% of the trees have been root-killed.

Naturally, fires during dry years are harmful because they magnify drouth stress on plants, whereas fires during wet years are generally beneficial because moisture is generally not limiting and fires increase soil temperature and stimulate nitrification.

As an example, in west Texas tobosa produced $2813 \mathrm{lb} /$ acre after burning during a wet year in 1969 and only 625 to $15 \mathrm{mph}$, and air temperature is 65 to $75^{\circ} \mathrm{F}$.

In addition to occurring during dry years, wildfires frequently occur during the active growing season, which is very untimely and severely damages many plants. For best results, burns should be conducted when preferred plants are dormant. In southern states, spring burning favors the desired warm season plants over cool season plants. By contrast, in the Northwest fall burning is preferred to minimize damage to the dominant cool season plants.

\section{Effect of Fire on Vegetation}

The usefulness of fire to stimulate forage production in stagnated grassland communities has been demonstrated by many researchers (Weaver and Tomanek, 1951; Weaver and Albertson, 1956; Ehrenreich, 1959; Hadley and Kieckhefer, 1963; Vogl, 1965; Wright, 1972a; and Anderson et al., 1970). Buildup of litter in excess of 2,000 lb/acre lowers soil temperatures, which reduces bacterial activity, ties up nutrients, and slows the general nitrogen cycling process, particularly during cool, wet years. In dry years, however, when wildfires are prevalent, litter is important for insulation and protection from flash floods.

Other benefits occur in the Great Plains. Cool season plants such as annual broomweed are easily controlled by spring burning (Wright, 1969). By contrast, the warm season perennial grasses are greatly favored. This is a good example of how fire can be used successfully as a management tool to depress one plant and enhance another. Moreover, the utilization of coarse, unpalatable species can be increased for 6 months to 1 year (Heirman and Wright, 1973; Klett, et al., 1971). Pricklypear, tasajillo (O. leptocaulis), and cholla can easily be killed with the use of fire (Heirman and Wright, 1973). Fire does not kill the pricklypear or cholla directly, but insects attack them after fire. We have recorded second-year mortalities of pricklypear after burning as high as $85 \%$.

In the Northwest, burning should be done in the fall to favor the dominant, cool season perennial plants. If burning is done in early summer, perennial bunchgrasses will be killed and annuals such as cheatgrass (Bromus tectorum) increase in dominance in the community (Wright and Klemmedson, 1965). Fall burning is one of the best treatments to retain desirable forbs and kill sagebrush (Artemisia triden- 


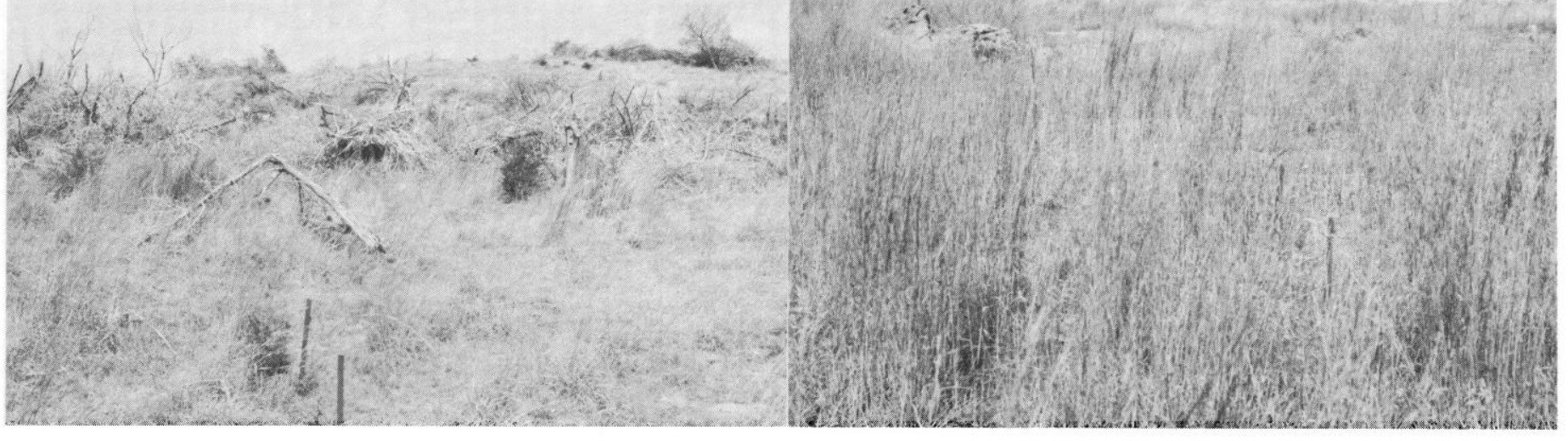

Fig. 3. Following tree-dozing and the establishment of young ashe juniper from seed (left), fire can keep grasslands relatively free of ashe juniper (right) for 15 to 20 years.

tata), although it temporarily harms bunchgrasses such as needleandthread (Stipa comata) and Idaho fescue (Festuca idahoensis) (Blaisdell, 1953; Wright and Klemmedson, 1965; Conrad and Poulton, 1966). Rhizomatous species such as thickspike wheatgrass (Agropyron dasystachyum and plains reedgrass (Calamagrostis montanensis) are favored by fall burning (Blaisdell, 1953). Undesirable shurbs such as horsebrush (Tetradymia canescens) and downy rabbitbrush (Chrysothamnus puberulus) are also favored by burning. Bitterbrush (Purshia tridentata) is severely harmed by burning (Nord, 1965).

Where fires are prevalent in grasslands, they have considerable value in controlling brush (Humphrey, 1958; Sauer, 1959; Wright, 1972b). Griffiths (1910) and Wooten (1916) believed that fires almost entirely prevented the establishment of undesirable shrubs in the southern desert. Griffiths stated that because of the slow growth of shrubs, he felt that they could be controlled by fires that occurred only once in 10 years. Drouth and competition from healthy grasses interact with fire to further restrict the growth of shrubs (Johnson, 1962; Wright, 1972b). However, when domestic livestock graze these grassland areas, competition from grasses is lessened, fires are less frequent, and shrubs increase.

Juniper is one of the best examples of a shrub being controlled by fire in grasslands (Fig. 3). Most species are nonsprouters and are readily killed by fire. Thus, juniper is generally found in the rougher and more dissected topography of grasslands (Wells, 1970).

By contrast, stagnant communities of chaparral are greatly rejuvenated by oc- casional fires (Hanes, 1971). Decadent stands of mixed-chaparral brush will produce 13 to $106 \mathrm{lb} /$ acre of browse (Gibbens and Schultz, 1963), whereas after burning these same communities produce from 750 to $2,750 \mathrm{lb} /$ acre (Biswell, 1969). However, fire is not necessary for true chaparral communities to maintain their identity (Hanes, 1971).

Shrub species which are dependent upon seed for survival, such as many juniper and chaparral species, can be eliminated from a community if fires are too frequent. This is why juniper is not a climax species on grasslands, but is climax on rocky breaks where it is protected from frequent fires (Burkhardt and Tisdale, 1969). Since nonsprouting species must reach a certain age to set seed (Hanes, 1971), a burning frequency of more than 15 years has been considered most desirable for the maintenance of these shrubs (Biswell, 1969). Otherwise, a change in the relative frequencies of various species of shrubs following fire will occur, as has been reported by Buell and Cantlon (1953) in New Jersey and Horton and Kraebel (1955) in California.

For years our forests were protected from fire by foresters whose training was dominated by European philosophy. Today we know that this was the wrong approach, because most of our forests evolved with fires. Without the natural sequence of fire, our forests have become plagued by inadequate reproduction, overstocking, stagnation, diseases and insects, as well as excessive fuel accumulation (Vogl, 1971). Protection of redwoods (Sequoia gigantea) in the Sequoia National Park has created a dog-hair thicket of young pines (Pinus ponderosa and $P$. lambertiana), white fir (Abies concolor), incense cedar (Libocedrus decurrens), and mature brush, with no regeneration of redwoods (Kilgore, 1970). Now expensive handwork, along with prescribed burning, is being used to protect these trees from the threat of disastrous wildfires and ultimate extinction.

Natural fires occur in ponderosa pine every 5 to 10 years (Weaver, 1951a; Kallander, 1969). They not only reduce hazards from wildfires, but they thin the stands, prepare a mineral seedbed for regeneration, and maintain a healthy understory (Weaver, 1951b). Shrubs are killed back, but most resprout vigourously and appear fully recovered 11 years after the fire. Prescribed burning techniques for this vegetation type have been developed by Biswell et al. (1955) and Buck (1971).

In the Douglas-fir zone of the Intermountain region, shrubs utilized by wildlife are favored by fires and have a dominant influence on plant communities for 20 to 50 years (Mueggler, 1965; Lyon, 1969). Species greatly enhanced by fire include Scouler willow (Salix scouleriana), serviceberry (Amelanchier alnifolia), Rocky Mountain maple (Acer glabrum), huckleberry (Vaccinium sp.), thimbleberry (Rubus parviflorus), and oceanspray (Holodiscus discolor). Scouler willow is especially abundant after burning (Mueggler, 1965; Leege, 1969). All of these species are sprouters and increase in density because root crowns of single plants produce multiple sprouts (Lyon, 1966).

Berry plants which are preferred by many species of wildlife,-blackberries, thimbleberries, raspberries (Rubus spp.), gooseberries (Ribes sp.), strawberries 
(Fragaria spp.), cranberries (Vibrunum sp.), huckleberries (Gaylussacia sp.), and blueberries (Vaccinium spp.)-thrive after fires. In forests of the northeastern United States, blueberries (Vaccinium angustifolium, $V$. myretelloides, and $V$. vacillans) persist for years in the understory of unburned communities as decadent plants. For maximum production of berries, they must be rejuvenated periodically by removal of dead or decadent stems and clones (Sharp, 1970). Brown (1960) found blueberries consistently more prevalent on areas with a fire history than on adjacent unburned communities.

\section{Effect of Fire on Wildlife}

Planned uses for wildlife should follow more of our prescribed burns and wildfires. It should not always be necessary to restock a forest with trees for the sole objective of growing as many trees as soon as possible. Land has many uses, as the United States Forest Service emblem depicts, and we should strive for variety. Variety is especially important in wildlife habitat management.

Following the Tillamook burns in Oregon that devastated 355,397 acres, deer and other wild animals and birds increased dramatically (Isaac, 1963). Not only was forage more plentiful, but the deer were healthy and free of liver fluke and lungworms that had plagued the coast deer herds for years before the wildfire. Biologists discovered that the fire had wiped out the dry-land snail, which is the intermediate host for liver fluke and certain lungworms over vast areas.

Deer, elk, moose, bobwhite quail, wild turkey, doves, prairie chicken, sharptails, ruffed grouse, waterfowl and many song birds are favored by fires which create variety in habitat (Miller, 1963; E. Komarek, 1963). The Kenai National Moose Range in Alaska is in the Boreal Forest and would never have been set aside as a moose range had it not been for the widespread fires occurring on the peninsula from 1870 to 1900 (Spencer and Hakala, 1964). Moose thrive on willow, quaking aspen, and shoots of paper birch (Betula papyrifera var. Kanaica), which grow luxuriantly after burns. By contrast, caribou are not favored by these browse foods. During the winter caribou feed principally on slow-growing lichens, some of which require more than a century for reestablishment following destruction by fire

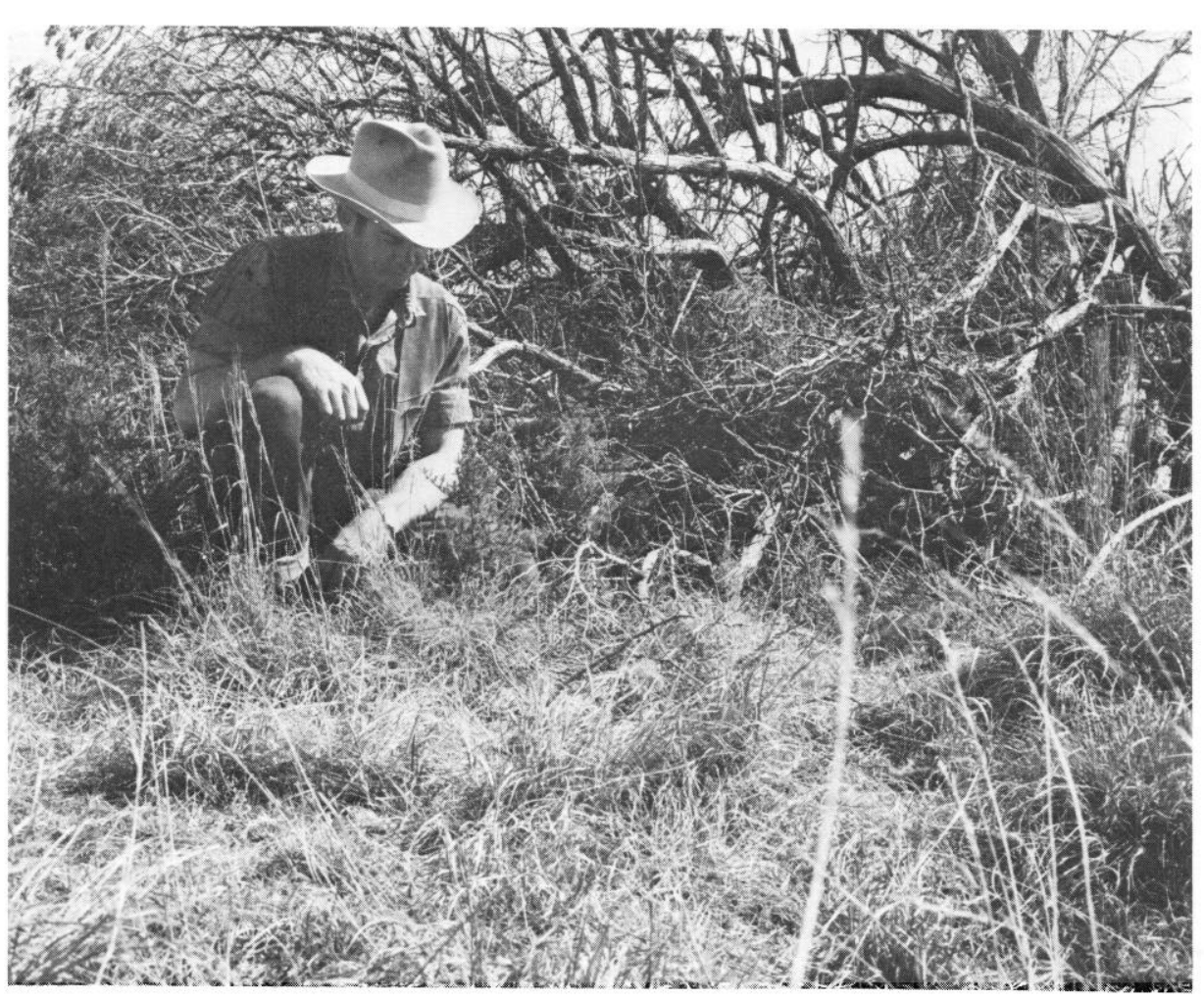

Fig. 4. Dozed ashe juniper in the background is a volatile fuel and gives off dangerous firebrands while burning. Grass in the foreground is a nonvolatile fuel and does not give off firebrands.

(Scotter, 1964).

Other subclimax animals that have reportedly increased following fires are cougars, wolves, coyotes, deer mice, ground squirrels, and beavers. Climax species such as bobolinks, sparrows, caribou, martens, wolverines, tree squirrels, and grizzly bear usually decrease.

Many people have a misconception about animals being killed by fires. Occasionally, animals are killed by fires, particularly large wildfires, but most vertebrates manage to escape the heat of fires by flying or running away, going below the ground a few inches, hiding in rock outcrops, or seeking islands missed by the fire. Studies in California by Howard et al. (1959) showed that fire did not harm cottontails, rats, mourning doves, quail, and several species of birds. In fact, the number of all animals increased immediately after the fire. Phillips (1965) listed a large number of ungulates associated with forests and woodland-savanahs in east Africa; the only report of any mature animals being killed by fire was after a fire in 1869 in which a dead elephant and buffalo were found. Phillips noted that occasionally a few species of very young animals were killed by fires.

Fires adversely affect population densities of animals principally by altering the habitat - not by killing. Habitat, more than anything else, determines the species and their densities. A patchy burn (about $20 \%$ unburned area) is most desirable for wildlife. This leaves adequate cover for upland and big game and a winter food supply of various nuts and acorns. Prescribed fires, in general, greatly increase the diversity of wildlife species, as well as population densities on all vegetation types (R. Komarek, 1963; Marshall, 1963).

\section{Techniques for Burning}

There are two basic fuel types (Fig. 4)-nonvolatile and volatile (fuels containing ether extractives such as waxes, oils, terpenes, and fats). Grasses and hardwoods are nonvolatile fuels, whereas chaparral, sagebrush, juniper, and slash are volatile fuels. Nonvolatile fuels such as grass are relatively safe to burn. Procedures to burn such fuels have been outlined by Wright (1972a). Volatile fuels, however, are explosive and create serious firebrand problems. They can be burned safely, but wide firelines and a thorough knowledge of weather and fire behavior are necessary (Green, 1970; Wright et al., 1972).

Our procedure for burning $4,000 \mathrm{lb} /$ acre or more of nonvolatile fuel is as follows:

(a) Cut a 10-ft fireline on the upwind sides of the area to be burned (Fig. 5). In this example we are assuming that the 
prevailing winds are from the southwest. (b) Cut a 15-ft fireline on the downwind sides (in this example north and east) of the area to be burned.

(c) Cut a 10-ft fireline $100 \mathrm{ft}$ inside the north and east sides (downwind).

(d) Backfire the 100-ft strip on the downwind sides when winds are less than $8 \mathrm{mph}$ and when relative humidities are between 50 and $60 \%$. The fire is very docile under these conditions and if a spot fire occurs, it can be easily extinguished

(e) After the downwind firelines have been burned, the main portion of the pasture can be burned with a wind that averages from 8 to $15 \mathrm{mph}$. Winds in excess of $8 \mathrm{mph}$ are necessary to burn down standing woody stems (Wright, 1972a). Relative humidities should average from 25 to $40 \%$.

These conditions can be varied with experience, depending on the amount of fine fuel and the goal of the burning. For example, a goal of killing shrubs or burning logs with light fuel (less than $2,000 \mathrm{lb} / \mathrm{acre}$ ), requires a wind in excess of $8 \mathrm{mph}$. If the only concern is to remove dead litter, a backfire for the main burn is sufficient. In practice, we usually burn around a prescription because the weather is seldom perfect.

The primary dangers in burning grasslands come from tumbleweeds and firewhirls. Tumbleweeds will ignite and then tumble, leaving flames in their path. Firewhirls develop where wind shears occur, such as when a headfire runs into a backfire, or a fire goes up slope into a wind. We have seen several firewhirls develop when headfires met backfires while winds were 10 to $15 \mathrm{mph}$. We have also seen two huge firewhirls develop when winds were light and variable. For these reasons, we prefer to burn with a steady wind and never burn into backfires, unless we have at least a $300 \mathrm{ft}$ fireline. Burning should be done with canyons, not across them.

Our procedure for burning volatile fuels on the Edwards Plateau in Texas is quite different (Fig. 6). It is illustrated below, where juniper has been dozed and there is adequate grass to carry the fire.

(a) Graze the pasture heavily before spring green-up.

(b) Doze 10-ft firelines on each side of a $400-\mathrm{ft}$ wide strip on the downwind sides (north and east in this example) of the pasture to be burned.

(c) While the grass is green (between May 1 and June 1), burn the large piles of dead fuel in the $400-\mathrm{ft}$ strips (black splotches in Fig. 6). Wind should be less than $10 \mathrm{mph}$, and relative humidity should be above $45 \%$. Care should be taken not to burn into areas with thick leaf mats of oak leaves. Oak leaves will ignitc casily from cinders. Wait at least

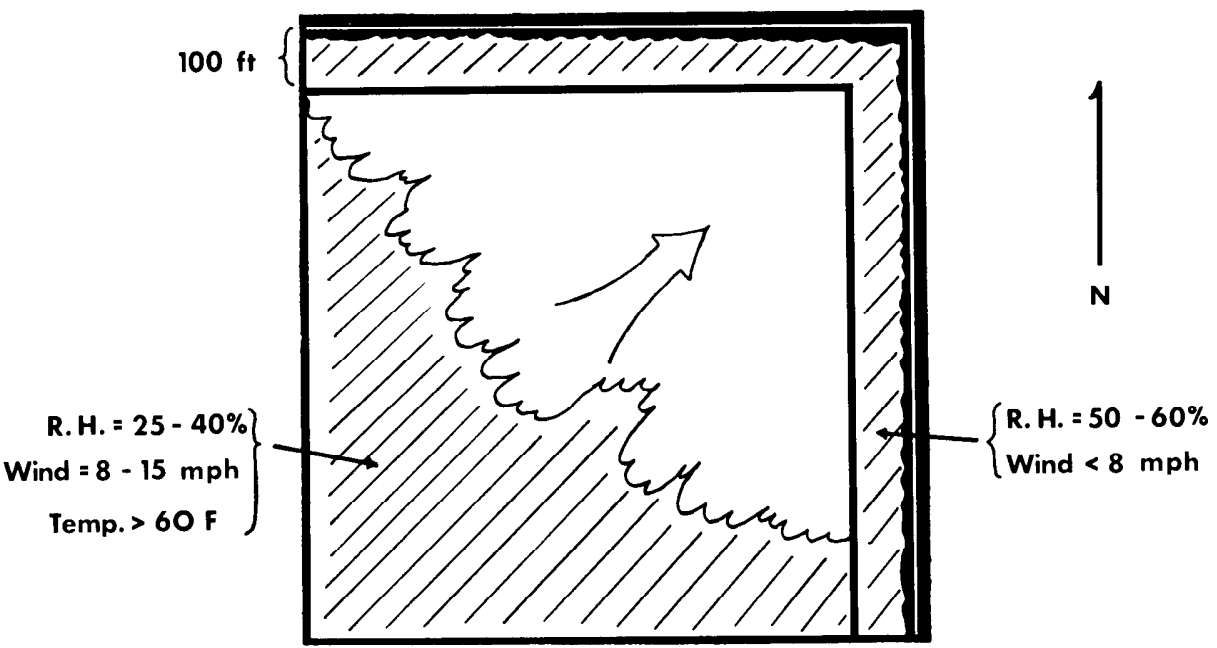

Fig. 5. After firelines are cut, a 100-ft strip on the downwind sides (north and east) of a pasture is backfired with winds less than $8 \mathrm{mph}$ and with relative humidities between 50 and $60 \%$. Then the pasture is headfired with the prevailing wind (southwest) averaging from 8 to $15 \mathrm{mph}$ and relative humidities from 25 to $40 \%$.

one day to burn piles of dozed juniper after receiving 0.25 inch of rain. Small piles must be dry to ignite easily and to burn completely. After pile burning is completed (June 1), defer the pasture so that adequate grass fuel will be available to burn the pasture the following spring.

(d) Eight months later in February, burn grass in the strips. If the grass fuel is more than 2,000 lb/acre (e.g. little blue- stem), burn when wind is less than $8 \mathrm{mph}$ and relative humidity is 50 to $60 \%$. If the grass fuel is less than $2,000 \mathrm{lb} / \mathrm{acre}$ (e.g. buffalograss), burn when wind is less than $8 \mathrm{mph}$ and relative humidity is 25 to $40 \%$. This prepares the firelines for the major burn that follows.

(e) Burn into the prepared firelines when wind is 8 to $15 \mathrm{mph}$ and relative humidity is 25 to $40 \%$. If there are large
FIRE PLAN FOR VOLATILE FUELS

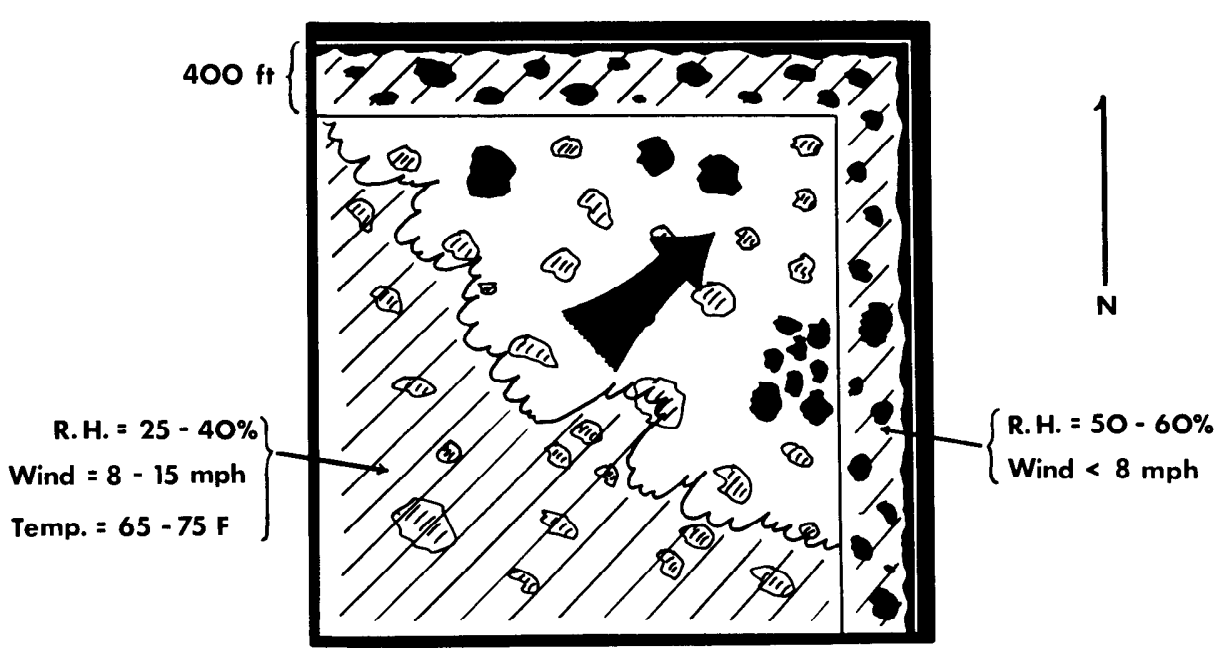

Fig. 6. When the grass is green, juniper piles in the 400-ft strip (black splotches) on the downwind sides (north and east) are burned with wind velocities less than $10 \mathrm{mph}$ and relative humidity above $45 \%$. Eight months later (when grass is dormant), the grass in the 400-ft strip is burned when the wind is less than $8 \mathrm{mph}$ and relative humidity is between 50 and $60 \%$. Lower relative humidities may be used if the grass fuel is less than 2,000 lb/acre. All large concentrations of piles are backfired on the downwind sides of main area to be burned, and then the entire area is burned into the prepared firelines with a wind of 8 to $15 \mathrm{mph}$ and a relative humidity of 25 to $40 \%$. 
concentrations of piles within 50 to $60 \mathrm{ft}$ of each other on the downwind sides, backfire them before headfiring the general area.

These volatile fuels put up live firebrands that can easily travel $1,000 \mathrm{ft}$ and ignite other fuels at this distance during dry years. Thus, weather at the time of burning is extremely important. Large piles of volatile fuels can be safely burned during dry, freezing weather, but flareups will be common during the following warm weather.

Current research also indicates that firebrands are not a serious problem when maximum winds are less than $5 \mathrm{mph}$, when 10-hr time-lag fuel moisture is over $15 \%$, when air temperature is below $60^{\circ} \mathrm{F}$, and when burns are conducted within 24 $\mathrm{hr}$ of a rain (Bunting, 1974). Any other time they can ignite punky wood or cow chips. They can also ignite bark and wood if the cinder is large enough and falls in a tight spot. Grass is very difficult for firebrands to ignite, unless the brands are flaming or they fall in a tight bunchgrass.

\section{Temperatures}

Mineral soil surface temperatures of grassland fires vary from $182^{\circ} \mathrm{F}$ to $1260^{\circ} \mathrm{F}$ for fuels that vary from 1546 to $7025 \mathrm{lb} /$ acre (Stinson and Wright, 1969). Temperatures above $150^{\circ} \mathrm{F}$ in these fires generally last only from 0.9 to $5.4 \mathrm{~min}$ utes (Stinson and Wright, 1969), which indicates that seeds of most plants can survive in grass fires (Daubenmire, 1968). Plant tissue, however, is easily killed with temperatures above $150^{\circ} \mathrm{F}$ that last from 1 to 12 minutes, depending on moisture content of the plant tissue (Wright, 1970). The relation between time and temperature to kill plant tissue is an exponential function (Hare, 1961).

Below the mineral soil surface, temperatures decrease sharply (Heyward, 1938; Bentley and Fenner, 1958). Under longleaf pines, where the principal fuel was grass, the majority of temperatures at depths of $1 / 8$ to $1 / 4$ inch in soil ranged from 150 to $175^{\circ} \mathrm{F}$ and generally persisted for 2 to 4 minutes, after which they declined rapidly (Heyward, 1938). Soil temperature increases were negligible below a depth of $1 / 4$ inch, even when flames were $12 \mathrm{ft}$ high.

Above the soil surface, temperatures rise very rapidly during fires (Bentley and Fenner, 1958; Ito and Iizumi, 1960; Whittaker, 1961). Whittaker found that some temperatures were $932^{\circ} \mathrm{F}$ greater at 8 inches above than at ground level. Davis and Martin (1960) measured temperatures as high as $1600^{\circ} \mathrm{F}$ at $1 \mathrm{ft}$ above a fire in 8 year-old gallberry-palmetto roughs. Where trees are present in heavy grass fuels, temperatures on the windward side are commonly $700^{\circ} \mathrm{F}$, while temperatures on the lee side are about $1400^{\circ} \mathrm{F}$ (Fahnestock and Hare, 1964). This is why trees are often scorched on one side only.

Bunchgrasses with large accumulations of dead plant material often generate high temperatures for a long period of time after the main fire has passed (Wright, 1971). The passing fire ignites the outer edge of the plant and then fuel within the plant generates temperature up to $1000^{\circ} \mathrm{F}$ within $1 \mathrm{hr}$. Temperatures above $200^{\circ} \mathrm{F}$ for over $2 \mathrm{hr}$ are common in large bunchgrasses, but not in small bunchgrasses or rhizomatous species.

Where heavy logs and deep brush are piled, duff surface temperatures vary from 1150 to $1841^{\circ} \mathrm{F}$ (Isaac and Hopkins, 1937; Bentley and Fenner, 1958). Maximum temperatures 3 to $15 \mathrm{ft}$ within and above brush piles are commonly $2000^{\circ} \mathrm{F}$ and can be as high as $2600^{\circ} \mathrm{F}$ (Countryman, 1964).

\section{Safety}

We have a major responsibility for conducting prescribed fires safely so that they do not go beyond the planned fire lines. Unfortunately, we only have minimal research data on how to conduct prescribed burns. We have a few excellent practioners around the world who know how to conduct prescribed burns, but their rules are general, sometimes regional in nature, and very little information is documented. For example, the people who burn in the Kruger National Park in South Africa do a lot of burning every year and are good at it, but they cannot tell us under what relative humidity, wind speed, fuel moisture, etc., they burn, except in relative terms.

To conduct burns safely, the fire boss needs precise research data on which to base a fire plan. We are getting this kind of data in Texas, and it is being collected in a few other states. We can give precise prescriptions to burn mesquite-tobosa and dozed ashe juniper communities.

Despite our efforts to get good fieldtested research on prescribed burns, we must still acknowledge that conducting prescribed fires is dangerous. People must be informed about these dangers-what they are and how we make plans to combat them. The unexpected behavior of a fire is always a threat, and only the man with years of experience can attempt to forecast most of the dangers. Thus, during the burning of volatile fuels, a dozer should be on standby and the area should be patrolled with pumper trucks.

Backfires are much safer to conduct than headfires, but they are also less damaging to brush species. Fast-moving headfires consistently do more damage to brush and trees than slow-moving backfires (Fahnestock and Hare, 1964). Backfires are also more difficult to keep burning in many fuel types unless the wind and relative humidity are unsafe. We prefer to use headfires as outlined previously. They are more destructive to shrubs and require less fuel to carry them.

As preparations for a burn begin, the fire boss should maintain contact with a fire weather forecaster from the U. S. Weather Service. These people are trained to give "spot weather forecasts" for specific areas, and give much better forecasts than the local area forecaster. It is generally necessary to follow weather patterns for several days ahead of a planned burn, so that you can pick an appropriate day for burning.

\section{Pollution}

Recent information on pollution from wood smoke has been summarized by Komarek (1970) and Dieterich (1971). In general, air-borne particulates are the primary pollutant of fires. However, they are short-lived. Hydrocarbons are another combustion product, but few, if any, appear in the combustion of wood products that are important in photo-chemical reactions (Fritchen et al., 1970). Carbon monoxide is a pollutant from fires, but it seems to oxidize quite readily (Fritchen et al., 1970) and does not pose an immediate threat to people, plants, or animals (Dieterich, 1971). Forest fires, including wildfires and prescribed burns, produce only $8 \%$ of all pollutants in the United States (Dieterich, 1971). This percentage can be influenced by the dryness of fuels at the time of burning. Dry fuels burn much cleaner than green fuels (Darley et al., 1966).

\section{Literature Cited}

Anderson, K. L., E. F. Smith, and C. E. Owensby, 1970. Burning bluestem range. J. Range Manage. 23:81-92.

Bentley, J. F., and R. L. Fenner, 1958. Soil temperatures during burning related to postfire seedbeds on woodland range. J. Forest. 56:737-740.

Biswell, H. H., A. M. Schultz, and J. L. Launchbaugh. 1955. Brush control in ponderosa pine. Calif. Agr. 9:3, 14.

Biswell, H. H. 1969. Prescribed burning for wildlife in California brushlands. Amer. Wildlife and Natur. Resources Conf. Trans. 
34:438-446.

Blaisdell, J. P. 1953. Ecological effects of planned burning of sagebrush-grass range on the upper Snake River plains. U. S. Dep. Agr. Tech. Bull. 1075. 39 p.

Brown, J. H., Jr. 1960. The role of fïre in altering the species composition of forest in Rhode Island. Ecology 41:310-316.

Buck, B. 1971. Prescribed burning on the Apache National Forest. p. 165-172. In Symp. on Planning for Fire Manage., Phoenix, Ariz. (Dep. Watershed Manage., Univ. Ariz., Tucson, Ariz.)

Buell, M. F., and J. E. Cantlon. 1953. Effects of prescribed burning on ground cover in the New Jersey pine region. Ecology 34:520-528.

Bunting, S. C. 1974. Ignition capabilities of non-flaming firebrands. M.S. Thesis. Texas Tech Univ., Lubbock, Texas. 38 p.

Burkhardt, W. J., and E. W. Tisdale. 1969. Nature and successional status of western juniper vegetation in Idaho. J. Range Manage. 22:264-270.

Conrad, E. C., and C. E. Poulton. 1966. Effect of a wildfire on Idaho fescue and bluebunch wheatgrass. J. Range Manage. 19:138-141.

Countryman, C. M. 1964. Mass fires and fire behavior. U. S. Forest Serv. Res. Paper PSW-19. 53 p.

Dahl, B. E., J. P. Goen, and B. Stelzer. 1971. Revegetation techniques and water use following mechanical and chemical brush controls. Noxious Brush and Weed Control Research Highlights, ICASALS Spec. Rep. $51: 26$.

Darley, E. F., F. R. Burleson, E. H. Mateer, J. T. Middleton, and V. P. Osterli. 1966. Contribution of burning of agricultural wastes to photochemical air pollution. J. Air Poll. Control Assoc. 16:685-690.

Dieterich, J. H. 1971. Air-quality aspects of prescribed burning. p. 139-151. In Proc. Prescribed Burning Symposium. Charleston, South Carolina. Southeastern Forest Exp. Sta.

Daubenmire, R. F. 1968. Ecology of Fire in Grasslands. p. 209-266. In Advances in Ecological Rescarch No. 5. Acadcmic Press, New York.

Davis, L. S., and R. E. Martin. 1961. Timetcmpcraturc rclationships of test headfires and backfires. U. S. Forest Serv. Fire Control Notes 22:20-21.

Ehrenreich, J. H. 1959. Effects of burning and clipping on growth of native prairie in Iowa. J. Range Manage. 12:133-138.

Fahnestock, G. R., and R. C. Hare. 1964. Heating of tree trunks in surface fires. J. Forest. 62:799-805.

Fritchen, L. J., H. Bovee, K. Buettner, R. Charlson, L. Monteith, S. Pickford, and J. Murphy. 1970. Slash fire atmospheric pollution Pacific Northwest Forest and Range Exp. Sta., USDA Forest Service Res. Paper PNW-97. 42 p.

Gibbens, R. P. and A. M. Schultz. 1963. Brush manipulation on a deer winter range. Fish and Game 49:95-118.

Green, L. R. 1970. An experimental prescribed burn to reduce fuel hazard in chaparral. Forest Service Res. Note PSW-216.6 p.

Griffiths, D. A. 1910. A protected stock range in Arizona. U. S. Dep. Agr., Plant Indus. Bull. 177. 28 p.
Hadley, E. B., and B. J. Kieckhefer. 1963. Productivity of two prairie grasses in relation to fire frequency. Ecology 44:389-395

Hanes, T. L. 1971. Succession after fire in chaparral of southern California. Ecol. Monogr. 41:27-52.

Hare, R. C. 1961. Heat effects on living plants. U.S. Dep. Agr. Occasional Paper 183. 32 p.

Heirman, A. L., and H. A. Wright. 1973. Fire in medium fuels of west Texas. J. Range Manage. 26:331-335.

Heyward, F. 1938. Soil temperatures during forest fires in the longleaf pine region. $J$. Forestry 36:478-491.

Horton, J. S., and C. J. Kraebel. 1955. Development of vegetation after fire in the chamise chaparral of southern California. Ecology $36: 244-262$.

Howard, W. E., R. L. Fenner, and H. E. Childs, Jr. 1959. Wildlife survival in brush burns. J. Range Manage. 12:230-234.

Humphrey, R. R. 1958. The desert grassland-a history of vegetational change and an analysis of causes. Bot. Rev. 24:193-252.

Isaac, L. A. 1963. Fire-a tool not a blanket rule in Douglas-fir ecology. Proc. Tall Timbers Fire Ecol. Conf. 2:1-17.

Isaac, L. A., and H. G. Hopkins. 1937. The forest soil of the Douglas-fir region and the changes wrought upon it by logging and slash burning. Ecol. 18:264-279.

Ito, M., and S. Iizumi. 1960. Temperatures during grassland fires and their effect on some species in Kawatabi, Miyagi Prefecture. Sci. Rep. Res. Inst. Tohoku Univ. D-Vol. 11(2): 109-114.

Johnson, T. N., Jr. 1962. One-seed juniper invasion of northern Arizona grasslands. Ecol. Monogr. 32:187-207.

Kallander, H. 1969. Controlled burning on the Fort Apache Indian Reservation, Arizona. Proc. Tall Timbers Fire Ecol. Conf. 9:241-249

Kilgore, B. 1970. Restoring fire to the Sequoias. Nat. Park and Conserv. Mag. 44:16-22.

Klett, W. E., Hollingsworth, D., and J. L. Schuster. 1971. Increasing utilization of weeping lovegrass by burning. J. Range Manage. 24:22-24

Komarek, E. V., Sr. 1963. The use of fire in wildland management. Proc. Ariz. Watershed Symp. 7:23-30.

Komarek, R. 1963. Fire and the changing wildlife habitat. Proc. Tall Timbers Ecol. Conf. 2:35-43.

Komarek, E. V., Sr. 1970. Controlled burning and air pollution: an ecological review. Proc. Tall Timbers Fire Ecol. Conf. 10:141-173.

Leege, T. A. 1969. Burning seral brush ranges for big game in northern Idaho. N. Amer. Wildlife and Natur. Resources Conf. Trans. $34: 429-437$.

Lyon, L. J. 1966. Initial vegetal development following prescribed burning of Douglas-fir in south-central Idaho. USDA Forest Serv. Res. Paper. INT-29. 17 p.

Lyon, L. J. 1969. Wildlife habitat research and fire in the Northern Rockies. Proc. Tall Timbers Fire Ecol. Conf. 9:213-227.

Marshall, J. T. 1963. Fire and birds in the mountains of southern Arizona. Proc. Second Annual Tall Timbers Fire Ecol. Conf. 2:135-141.

Miller, H. A. 1963. Use of fire in wildlife management. Proc. Tall Timbers Fire Ecol.
Conf. 2:19-30.

Mueggler, W. F. 1965. Ecology of seral shrub communities in the cedar-hemlock zone of northern Idaho. Ecol. Monogr. 35:165-185.

Phillips, J. 1965. Fire-as Master and Servant: Its influence in the bioclimatic regions of Trans-Saharan Africa. Proc. Tall Timbers Fire Ecol. Conf. 4:7-109.

Scotter, G. C. 1964. Effects of forest fires on the winter range of barren-ground caribou in northern Saskatchewan. Canadian Wildlife Service. Bull. Ser. 1, No. 18. 111 p.

Sharp, W. M. 1970. The role of fire in ruffed grouse habitat management. Proc. Tall Timbers Fire Ecol. Conf. 10:47-61.

Spencer, D. L., and J. B. Hakala. 1964. Moose and fire on the Kenai. Proc. Tall Timbers Fire Ecol. Conf. 3:11-34.

Stinson, K. J., and H. A. Wright. 1969. Temperatures of headfires in the southern mixed praire of Texas. J. Range Manage. 22:169-174.

Vogl, R. J. 1965. Effects of spring burning on yields of brush prairie savanah. J. Range Manage. 18:202-205.

Vogl, R. J. 1971. The future of our forests. Ecol. Today 1:6-9.

Weaver, H. W. 1951a. Fire as an ecological factor in the southwestern pine forests. J. Forest. 49:93-98.

Weaver, H. W. 1951b. Observed effects of prescribed burning on perennial grasses in the ponderosa pine forests. J. Forest. 49:267-271.

Weaver, J. E. and F. W. Albertson. 1956. Grasslands of the Great Plants. Johnson Publ. Co., Lincoln, Neb. 395 p.

Weaver, J. E., and G. W. Tomanek. 1951. Ecological studies in a midwestern range: the vegetation and effects of cattle on its composition and distribution. Neb. Conser. Bull. $31.82 \mathrm{p}$.

Wells, P. V. 1970. Postglacial vegetational history of the Great Plains. Science 167:1574-1582.

Whittaker, E. 1961. Temperatures in heath fires. J. Ecol. 49:709-715.

Wooten, E. O. 1916. Carrying capacity of grazing ranges in southern Arizona. U. S. Dep. Agr. Bull. 367.40 p.

Wright, H. A. 1969. Effect of spring burning on tobosa grass. J. Range Manage. 22:425-427.

Wright, H. A. 1970. A method to determine heat-caused mortality in bunchgrasses. Ecology 51:582-587.

Wright, H. A. 1971. Why squirreltail is more tolerant to burning than needle-and-thread. J. Range Manage. 24:277-284.

Wright, H. A. 1972a. Fire as a tool to manage tobosa grasslands. Proc. Tall Timbers Fire Ecol. Conf. 12:153-167.

Wright, H. A. 1972b. Shrub response to fire. p. 204-217. In Wildland and Shrubs-Their Biology and Utilization. An International Symposium, Utah State University, Logan, Utah. USDA Forest Service Gen. Tech. Rep. INT-1.

Wright, H. A., C. M. Britton, R. L. Wink, and B. Beckham. 1972. A progress report on techniques to broadcast burn dozed juniper. Proc. Tall Timbers Fire Ecol. Conf. 12:169-174.

Wright, H. A., and J. O. Klemmedson. 1965. Effects of fire on bunchgrasses of the sagebrush-grass region in southern Idaho. Ecology 46:680-688. 